\title{
Supreme Court as Court of Record
}

\author{
Mayank Vats, Leepakshi Rajpal
}

\begin{abstract}
This paper primarily focuses on the concept of the Supreme Court as the court of record. It commences with the introduction about the topic and specifically about the Supreme Court. As it approaches further in its essence, it talks about the history of the Supreme Court of India. In this part it mentions about the history of the supreme Court as to when was it set up and where was it set up. It also discusses in detail about the need to have the Supreme Court at that time. It also discusses the aspects of the Supreme Court as to how was it set up and particularly what was the situation when the Supreme Court of India was set up and then why it had to shift its base to New Delhi and when. Moving ahead in the topic, this paper discusses about the Court of record. It discusses in detail its meaning, its vitality and the apprehension of trust that is bestowed upon it. After knowing the meaning and the concept of the Court of Record, this paper finally comes to the main subject of the paper which is to analyse the Supreme Court as the Court of Record. As I moves further in its approach, it discusses how Supreme Court has achieved a reasonable success in the meaning of the term the court of record and has proved to be one of the best courts in the world. It also discusses the lacunae involved in the Indian Supreme Court. Last, but not the least this paper ends with certain sets of recommendations and conclusions with regard to the improvement and reforms in the Indian Supreme Court. This paper aims to sensitise the youth towards the importance of the Supreme Court and how its history is admissible in the legal career.
\end{abstract}

\section{RESEARCH METHODOLOGY}

\section{Scope and Objective of the Study}

The object of the study is to analyze the Supreme Court of India as the court of Record. A study of the History of the Supreme Court is conducted in order to bring out the best int his article and to provide maximum knowledge to the reader. However, we agree to the fact that no matter how much we write about the Supreme Court of India, its legacy has to continue and being in the legal learning stage, we feel delighted to have chosen this career. Various attempts have been made to make suggestions which can bring reform in the condition of Indian Supreme Court to enable it to dispense the best of the decisions with righteous intentions and in order to provide indispensible justice to the people whose fundamental rights have been violated, so that they can be in equal line with the other people of the country, so far as the concept of Justice is concerned and also so that the Supreme Court can be at par with the other Supreme Courts of the International base, as far as keeping and maintaining records is concerned. This paper discusses about the legacy of the Supreme Court since its very inception and how things have changed after its inception. It also discusses about the dynamic role played by the Indian Supreme Court in deciding several cases which have been remarked as one of the hallmark cases of the Indian Judiciary. The study is limited to the concept of Supreme Court as the Court of Record, so as to be very clear and precise in its approach.

\section{Research Methodology}

The methodology adopted is largely analytical and descriptive. Reliance has been placed largely on secondary sources like books and articles. The lectures and classroom discussion have been rich with valuable pointers and gave direction to the research.

\section{Chapterization}

This project has been divided in chapters. It consists of following chapters, Introduction (Chapter I), Historical Background (Chapter II), The Supreme Court as Court of Record (Chapter III), and Conclusion (Chapter IV)

\section{Research Questions}

1. What is the history of the apex court of India or the Supreme Court Of India and what is its relevance? 
2. What is a Court of Record and how does it frame the Judiciary?

3. How can we say that the Supreme Court is the court of Record and what role does it actually play in framing the boundaries of the Indian Judiciary and Supreme Court to be very precise ?

4. What is the conclusion drawn from the research done?

\section{Hypothesis}

While attending to the concept of Court of Record, some major issues that came into my mind is that whether a The Supreme Court of India which is the apex court India has, can be called as a court of record or whether it has ever been entitled to such a position of the court of record. Another important issue that arose while doing the research is that how did the Supreme Court come into existence ? and how do we know that Supreme Court is the apex court and who had this idea of bringing in the concept of Supreme Court. Another important issue is that what was the need of setting up the Supreme Court when there were already three courts in the country and by this we mean what was the essence of setting up the Supreme Court ? Another important issue that arose was that how can we call the Indian Supreme Court to be the court of record, when all the court hold with them records with themselves so as to be assure of the cases decided in the particular court. Has the Indian Supreme Court been entitled to the position of the Court of Record, If yes then when and by whom ?. Another important issue incessant to the latter one is that who has the authority to give titles to the Indian Supreme Court and why is the Supreme Court considered to be Supreme and its decision is binding on all the other courts. This all will be dealt by us in the following paper and this paper will strictly adhere to the secondary sources of information, i.e. the books, articles, online information and the general knowledge of the author.

\section{Mode of Citation}

A uniform system of citation is followed throughout in the contents.

\section{CH-1. INTRODUCTION}

This part of the research paper primarily focuses on the introduction of the Supreme Court of India. It is very important to know what the Supreme Court means and what it really is before going into other details of the research, therefore this part deals with the brief introduction of the Supreme Court of India.

India is a federal country and in a country so diversified in its essence, how does the law operates ? The powers are divided among the legislature, executive and the judiciary, where the legislature has the power to make laws, the executive has the power to implement laws and the judiciary has the power to interpret the laws and enforce them. All the three organs of the government are interdependant on each other in some or the other way, be it minute or grave. When it comes to the division of power within the legislature, it is usually discussed as to what law will be made by what organ off the legislature. The legislature is at the centre, state and the local level too, so who has the power to make laws regarding what subject matter is the question.

There are three lists provided in the Constitution of India which determine as to what law will be made by whom. List I contains and prescribes the subject matters regarding which the union government is supposed to make laws. This list is known as the Union List. List II contains the subject matters on which the State government is supposed to make laws and that is why the list is known as the state list. The third and the most complicated is the concurrent list which is the List III. This list contains those subject matters over which no one either the centre or the state has exclusive jurisdiction over and the subject matters do not come personally under any of the lists. Therefore, in the matter of governance of the subject matters mentioned in the List III, both the Union and the State decide as to what is to be done and in case there are conflicting views of the Centre and the State, then it is the will of the centre that will prevail over the State. This is primarily because the Union is considered to be the supreme government of the nation and therefore, it has the power to make laws in the concurrent list and the opinion of the Centre will be considered in case of a tiff between The Centre and the State. This was in context of who makes the laws, now when it comes to the interpretation of these laws, the judiciary comes into the picture.

In any country, Judiciary plays a very important role in the interpreting and applying of the law and adjudicating upon the controversies that arise between one citizen and another citizen, and between a citizen and a state and between two states as well. It is the function of the courts to maintain the law 
and order and ensure a peaceful operation of the societal peace and the actions of the people which are in compliance with the rules and regulations provided by the law of the land and the supreme law. It is an important function of the court to ensure that the government runs according to the procedure established by law and does not try to run in an autonomous direction. In a country like ours, with the written constitution, the courts have an additional function of safeguarding the supremacy of the Constitution by interpreting and applying its provisions and keeping all the authorities in the constitutional framework.

In a country like ours, India, the judiciary has an even important role to play in the good governance of the country. The judiciary also has an important role to protect and safeguard the fundamental rights of the people and guaranteed to them by the Constitution of India. Justice Untwalia has compared the judiciary to " a watching tower above all the big structures of the other limbs of the state from which it keeps a watch like the sentinel on the functions of the other limbs of the state as to whether they are working in accordance with the law and the constitution, The Constitution being supreme"1. According to the words of the Hon'ble Justice Untwalia, the Judiciary plays a role of the watchman, which keeps a check on the smooth running of the governance of the society, where in the people of the society are acting in accordance with the law or the procedure established by law and the Constitution specifically, where the procedures established and mentioned in the Constitution of the country are the supreme and nothing can go against the Constitution of India.

India has been a unified judicial system with the Supreme Court standing at the apex ${ }^{2}$. This means that among the levels on the Judiciary the Supreme court is the apex court i.e. the highest court and nothing shall disobey the orders of this court or shall be charged for the contempt of court. The orders and the discretion of the Supreme Court is the highest and is binding on all the other lower courts, however the Supreme court has the power to adjudicate only the judicial matters and does not have the administrative powers over the High courts. There are High courts below the Supreme court, and under each High Court there exists a system of subordinate courts. So, there is a hierarchy of the system that exists and nothing is disorganised or unorganised when it comes to the Judiciary on India. The Supreme Court thus enjoys the topmost position in the judicial hierarchy of the country. It is the Supreme interpreter of the Constitution and the guardian of the people's fundamental rights. It is the ultimate court of appeal in all the civil and the criminal matter and the final interpreter of the law of the land, and thus helps in maintaining a uniformity of law throughout the country.

Article 124 (1) of the Constitution of India ${ }^{3}$, establishes the Supreme Court Of India. The chief justice of the court is designated as the Chief Justice of India. The Supreme Court of India is located at New Delhi and sits at Delhi, or at such other place at which the Chief Justice of India may, with the approval of the President, appoint from time to time ${ }^{4}$.

Explaining what is said above under Article 130 of the Indian Constitution, the Supreme Court has stated in the Union of India v. Anand ${ }^{5}$ that it is an enabling provision and does not cast mandatory obligation on the part of the Chief Justice of India to appoint any place other than Delhi as the seat of the Supreme Court Of India. Whether the Supreme court should sit at the place other than Delhi involves taking a policy decision by the Chief Justice of India which must receive the approval of the President of India, as stated in the above paragraph. This means that if the Chief justice of India wants that the court should sit somewhere else other than in Delhi, then he has to take prior permission of the President because this involves taking an policy making decision which cannot be taken alone by the Chief Justice of India and hence the permission of the President of India is required for the same.

When the courts of the country have to take decision in such a haste manner, effective working of the courts is the key to the efficient workers in the Judiciary itself. To enable the courts to discharge their multi-faceted functions effectively, it is extremely important that the courts enjoy independence from

\footnotetext{
${ }^{1}$ Union of India v. Sankalchand Himatlal Sheth, AIR 1977 SC 2328

${ }^{2}$ However, the Supreme Court does not exercise the administrative powers over the High Courts.

${ }^{3}$ Article 124 of the Indian Constitution states the following :-

Establishment and constitution of Supreme Court
}

(1) There shall be a Supreme Court of India constituting of a Chief Justice of India and, until Parliament by law prescribes a larger number, of not more than seven other Judges.

${ }^{4}$ Article 130 of the Indian Constitution of India.

${ }^{5}$ AIR 1998 SC 2615 
both the other organs i.e. the legislature and the executive, so as to ensure the smooth, fair, just and reasonable functioning of the courts. Therefore, the independence of the Judiciary has become the basic creed in a democratic society like ours. The need for judicial independence becomes all the more important in India as Judicial review is regarded as the 'fundamental feature' of the Indian Constitution.

The judicial plan of 1793 was the best among all the plans till now and entailed a complete restructuring of the judicial system. It brought in more accuracy and accountability into the system. It also marked a great reduction in the number of courts.

The Court structure that we have today, in addition to the actual laws itself are greatly due to the efforts of the British Government. Their motives for creating such a large system that has continued to exist well after independence may not have been the most noble; it is however impossible to deny or discount their presence in our legal system today. What existed prior to the modifications and consolidations by the British hand, was a largely unorganised area which gave decisions that were neither fair, nor could be brought to scrutiny via any standard. The very enactments of the British legislature in India are to be credited for the setting up of a definite court structure.

\section{CH-2. HISTORICAL BACKGROUND OF THE SUPREME COURT OF INDIA}

In the above chapter, we talked about what is the Supreme Court but in this chapter in furtherance to what we have already learnt, we will be learning about where did this concept of Supreme court came from and what was there when the Supreme court did not exist and how did people at that time used to administer justice to their fellowmen and others and what was the whole concept of the Justice all about.

So, as we are talking about historical background, it is obviously prior to the establishment of any proper legal system regarding the administration of Justice on India. The system was an extremely decadent system and the existence of such a system was injustice itself ${ }^{6}$. The system was not accessible to all the people so easily, nor they depended on those who imparted a fair and equitable judgement. In addition to that, the offence committed was sometimes of a petty nature and the punishment was grave and in other cases the offence committed by the accused was of a grave and intense nature, whereas the punishment given for the same was meagre. There was a lot of disproportionality when it came to the imparting of justice which was fair, just and reasonable. It was in the early times that the concept of Dharma or law in the ancient India, was inspired and regulated by the texts like the Vedas which contained rules regarding the conduct of the people and the rites which were guaranteed to the people at that time and which were complied in the Dharma Sutras and were practiced in a number of branches of the Vedic schools ${ }^{7}$. Their principal contents address the duties of the people at various stages of life, their rights, the duties of the kings and the juridical matters of their courts. These were the basis of the Hindu law.

The earliest document that throws light on the theory of jurisprudence is the Artha Sastra by Kautilya dating back to the 300 B.C.. The third chapter of the Artha sastra deals with the Vyavhara, i.e. the transactions between two or more parties or Vivada or disputation. It was after some period of time during the first seven centuries of the Christian era, that there evolved a number of Dharma Sastras which dealt with the Manusmriti, Yajnavalka, Narda and the Parashara Smritis etc. ${ }^{8}$ It was in reference to this that the laws were made and the people were governed. People were misguided and were misled regarding justice. The decision makers of the society were usually the elderly men and the decisions were not fair, rather they were usually unfair and biased. The corruption was so rampant even in the ancient days that people did not get justice even when the unofficial institutions were set up for the disposal of justice.

It was in Medieval days, when the religious leaders planned to transform Islam into religion of law, but as a custodian of justice, the rulers made the Sharia, which was supposed to be serving the purpose of the legislations and the laws that we have today in those times. The rulers had to be the followers of the Sharia and historical evidences prove that the sovereign decision was sometimes left

\footnotetext{
${ }^{6}$ Shambhavi Ravishankar, On the Understanding of the Creation of the Indian Judicial System, Academike www.lawoctopus.com

${ }^{7}$ Ibid.

${ }^{8}$ Ibid.
} 
to the discretion of the Quazi. The rulers sat in the court known as the Mazalim which meant complaints. According to Ibn Battuta, The ruler of the Tughlaq dynasty, i.e. Muhammad bin Tughlaq sat in the court each Monday and Thursday. The local law officers that we had were very prone to corruption and their decisions were dominated by mala fide. The local officers such as the Kazis, the Muftis and the Maulavis were very prone to deciding cases in the favour of the people who paid for the decisions that they wanted to be given, i.e. the people who paid for the already taken or biased decisions, which directly defeated the function of the court and its sole purpose sending a highly incorrect message to the public to whom the justice is meant to be disposed. During the medieval period, the Muftis were the expert on Sharia law and gave Fatwas (formal legal rulings) on disputes referred to them by the members of the public or the qazis. The Chief Judge of the sultanate was known as the qazi-i-mamalik also known as the qazi-ul-quzat. During Mughals period the secular judge was known as Mir-adl. He acted as a judge on the Emperor's behalf. He was required to make impartial decisions but irrespective of the duty he was supposed to perform there were loopholes in his efficiency of work and therefore the disposal of justice was inefficient on the outlook. In the Mughal Empire, when it was at its peak of the power, had employed two officers in order to conduct the administration in the provinces also known as the Subah's and the officers were known as the Subehdars, and they were divided into the Nawab and the Diwans ${ }^{9}$. The Nawab handled the matters of the military and criminal justice and law order while the Diwan handled the matters with regard to the revenue collection and the administration of the civil justice and revenue cases and disputes ${ }^{10}$ and the same system was followed till British overtook the Indian administration.

Coming to the next phase of the Indian history when the British took over the administration of India. In this part we will see, how the British colonialists framed the system for the judiciary to work efficiently or inefficiently in the country. The Indian systems or the judicial system under the Mughals and even previously, they proved to be extremely inefficient in carrying out their judicial responsibilities. One can fairly deduce from their activities that they were highly disinterested in the performance of these functions. In that time too they delegated their work to their assistants Darogaadalat-al-alia as the assistant of the Nawab, and the Daroga-i-adalat, for the Diwan. But they were again very corrupt due to the acceptance of bribes and money in order to adjudicate the matters. Therefore, at least curroption is not new when it comes to the discussion of Judicial History of the same. It was only after the English East India Company attained the right of Diwani which gave them the powers to adjudicate upon the matters of the civil and criminal nature that they acquired the land slowly and gradually with the help of their minds and politics. then they brought in Lord Hastings to turn things around. They wanted him to create a uniform system, a system that would be people friendly and serve justice according to the natural principles of justice. Furthermore they needed a system which was more simple and efficient in order to dispose of Justice to the Indian people. They had two main motto behind the same :-

Collection of the revenue for the English East India Company, creating a uniform and easily understandable system of justice that was people friendly and that aided not just the British nationals in the country but also the natives living within their territories. This was the job of Warren Hastings, when he was the Governor of Calcutta. He was asked by the board of directors to reduce the pressure and torture on the zamindars and other officials who were over using their power for all wrong reasons, thereby increasing the pain, grief and anger among the local, poor and Indian peasants. It must be noted that the British were extremely prudent in realising the unmistakable link between the revenue and the civil matters, that they played this cunning game with the Indian local peasants who were so poor that they could hardly sustain themselves in their reign. Realising this they knew that their aims were easily achievable in India but more importantly that the interests of the people were neither neglected nor forgotten ${ }^{11}$. These were the conditions on which Warren Hastings was introduced as the governor of the state of Calcutta and was also given the task of setting up the new legal system in India, which ultimately came to be known as the Adalat system.

Warren Hastings was the first Governor general of India and his duty for India was a big one. He was given the duty to set up the legal system in India and he started one from Calcutta being the governor general of Calcutta. But he came into a situation of turmoil and disarray with respect to the judicial

\footnotetext{
${ }^{9}$ Ibid.

${ }^{10}$ Prof. M. P. Jain, Outlines of Indian Legal \& Constitutional History, (6 Edition), Ch 7, Pg 54.

${ }^{11}$ Supra 6.
} 
isntitutions and their administering of justice. The institutions that existed were corrupt and inefficient, they could not solve the purpose of Warren Hastings being here in the country. Moreover, these courts were not accessible to all and especially were not available to the common masses to whom the Justice should have been rendered, and these masses were forced to incur a great amount of expense and travel in order to attain justice. This was the situation that Warren Hastings was given the mission of turning around and his rigorous attempts to transform the judicial system were categorised in two plans, i.e. the Judicial plan of 1722 and the Judicial plan of $1774{ }^{12}$.

Under the judicial plan of 1722, the basic idea of Hastings was to re structure the area and appoint officer for the collection of revenue in each area, the district being the smallest area. Areas of Bengal, Bihar and Orissa were divided into districts and the collection of revenue was done by the revenue officers in these states. The Adalat system had to brought in the practice at this time and the hierarchy of the courts had to be set in.

A small cause adalat was set up in order to deal with the petty cases dealing with not more than the value of Rs. 10. The head of the village was given the duty of administering and delivering justice at the very small level and this was a kind of local level government or panchayat at that time and he also had the duty of collection of revenue so that there is an in built system of checks and balances ${ }^{13}$. By bringing the head of the village as the person administering justice, it was less likely that he would perform arbitrary activities because he had the trust of the people of the village and his activities were also closely observed by the superior authorities.

Above these Small cause adalats were the Mufassil adalats popularly known as the mufassil fozdari adalat or mufassil nizamat adalat. These courts particularly dealt with the administration of the criminal justice. The collector was the person who was authorised to be supervising the Adalat. The sessions in this court were held regularly and the judgements rendered were impartial and fair rather than the earlier system where everything was unfair. But apart from this, the Muslim law officers, the Kazis, the Muftis, and the Maulavis were there to interpret the Muslim laws which were to be applied to the muslims and they were to give the Futwas ${ }^{14}$ and give the judgement.

Above these courts were the Sadar-diwani Adalat and the Sadar Nizami adalt. These courts heard appeals from the lower courts of maximum value of Rs. 500. It had the governor and the members of the council as its chief members. The court fees that was charged was about $5 \%$ for the cases of appeal and the appeal had to be made within a period of two months ${ }^{15}$.

These were the hierarchy of the courts that was set up and the role of East India company was limited only till the Diwani courts and hence their role in the criminal judicature was minimal. It was restricted to the extent of the Governor and the Council exercising supervisory control over the court's functioning. In truth, the British had no right to administer criminal justice as that still came under the purview of the Nizam and his assistant.

The plan had some amazing reforms in the set but there were many pitfalls of the plan, one of them included that there was too much power in the hands of the Collector, and this was a negative thing as the collector could misuse his powers, which would in turn defeat the purpose of justice. In order to tackle the problem of corruption amongst the native law officers, Warren Hastings ensured that officers were given a proper regular salary, so as to ensure a good level of objectivity in delivering judgements that are fair and unbiased as it earlier used to be. This step of providing them salary was one of the best steps ever taken to ensure proper justice, but as far as its implementation and the question of unsatisfying wants arises, we are really sceptical about the approach of the officers, because the greed inside the human drives a human being for more and to attain that more, it is in the psyche of the human being to go on unwanted paths.

Also, there was a pre set amount of the court as the fee, which was set by the government so as to ensure that the justice is easily accessible to all and to prevent corruption even amongst the judges. It also ensured that the judges charged reasonable and fair and not something that went beyond the

\footnotetext{
${ }^{12} \mathrm{http}: / /$ www.encyclopedia.com/topic/Warren_Hastings.aspx.

${ }^{13}$ M. P. Jain, Outlines of Indian Legal and Constitutional History, (6 Edition) Pg 57.

${ }^{14}$ Futwa is the Urdu word denoting the law applicable to the circumstances of the case. It was to be according to Mohammedan law.

${ }^{15}$ Mofussil Diwani Adalat.
} 
capacity of a normal and an average person of the area. But there was another problem that there was a dearth of courts and hence the justice was very difficult for an ordinary prudent man to reach out to. Considering these problems as grave Warren Hastings went in for another plan that is the judicial plan of 1774.

The plan of 1774 mainly focussed on solving the problem of the scarcity of adalats to which the people had the approach to and were accessible to. Each of the divisions consisted of several districts. From theses districts the collector was removed and a new post called the Diwan or amil was created. This Amil was given the functions of collecting the revenue and Presiding over the Mufassil Diwani Adalat ${ }^{16}$. Now, in each division a Provincial Council was instituted to hear appeals from the Mufassil Diwani Adalat and also to supervise the collection of revenue. The Provincial council had four to five English East India Company officials. If there was a case of more than Rs. 10000 then the case would be dealt by the Sadar Diwani Adalat. The provincial council exercised the original jurisdiction to hear cases that arise within the limits of the town where it was seated. So, not only it was the link between the mufassil and the sadar diwani adalats by exercising appellate jurisdiction, but it also had the power to be a court of first instance. Another important aspect of this plan was that the Mufassil Diwani Adalat was presided over by the diwan and there was no more pecuniary limit of the caase being above Rs 500 to move from Mufassil Diwani Adalat to the Sadar diwani adalat ${ }^{17}$.

The judicial plan of 1774 was however, not flawless. Hastings himself foretold the corruption and the internal discretion that would be created due to the existence of the Provincial Council. He reasoned that the collector according to the plan of 1772 was a petty officer, who if he committed any such fraudulent practices could be checked by his seniors. But the provincial council was made up of fairly senior officers of the East India Company, and little could be said or done to stop them from overdoing things or misusing their powers ${ }^{18}$.

It was after this that Lord Cornwallis came into picture and then devised new forms of laws and regulations. He was the first Governor-general under the new regulating act of 1773 which allowed the creation of the Supreme Court in Calcutta. In his tenure he was able to balance the tenure between the English East India Company as well as the interests of the people. He did not just focus on the East India Company's goals, or the repayment of the loan that they had undertaken from the Crown. He was able to defy the mercenary interests of the East India Company when they conflicted with the State policy ${ }^{19}$. His tenure was extensively productive in terms of the number of reforms brought out to better the judicial system. He basically introduced the new reforms in every sphere be it criminal or civil judicature, in re organising the districts and introducing for the first time the principle of administration according to the law ${ }^{20}$. His contribution to the existing judicial system can broadly be classified under the following three judicial plans , i.e. the Judicial plans of 1787, 1790 and 1793.

The plan of 1787wanted to achieve fair justice and the only way to this was the increase in the salaries of the collectors by reducing the number of districts and each of these districts would have a collector and the collector would collect the revenue as well as administer justice in the district and this collector will be a representative of the East India Company. For the disputes related to the revenue collection related disputes another tribunal was set up known as the Mal adalat, over which the collector will preside and will also preside over the mufassil diwani adalat. It was with regard to the criminal judicature that the person who took the cognisance of the criminal affairs, in order to issue warrants for people's arrest in order to be able to send them to the mufassil nizamat adalat, but despite this, the collector could not sit for all the cases and for all the time. The collector was given the allowance of meting out punishments of upto 15 days imprisonment or 15 strokes or both. This plan was highly inefficient as it was set up in a manner that it was bound to fail because the collector was vested with too much of power and there was no balance of power, so much so that he was over worked. Secondly, he could misuse the power in an abrupt manner and none could stop him from doing that and another loophole was that the criminal and the civil judicature were overlapping.

The next plan of Lord Cornwallis was the Judicial Plan of 1790 and this plan aimed at changing the system of the courts followed and the laws implemented in the criminal justice system. Also a new

\footnotetext{
${ }^{16}$ Mofussil Diwani Adalat

17 Sadar Diwani Adalat

18 M. P. Jain, Outlines of Indian Legal and Constitutional History, (6 Edition) Pg 61.

${ }^{19} \mathrm{http} / / / \mathrm{www}$. indianetzone.com/39/lord_cornwallis_indian_governor_general.htm.

${ }^{20}$ M. P. Jain, Outlines of Indian Legal and Constitutional History, (6 edition), Pg 119.
} 
hierarchy of courts was established and it was a three tier arrangement, in which the lowest level was that of the magistrate in the district and then the court of circuit and then the Sadar nizamat adalat. The special thing about the court of circuit was that the court was not stationary and it could move from place to place being accessible to the people and bringing justice to the people. This plan was a better plan than the previous one but again it was inefficient because of the corruption at the level of each officer employed for the disposal of justice.

Now, you will question as to why this is importnat, but one thing to ponder upon is the vitality of the setting up of the supreme court under the governance of Lord Cornwallis and not only that but the hierarchy of the court system was different from that we follow today and thus making us realise that we can improvise in the system even today when we find a loophole in the functioning of the Indian Judicial system. It was later that the Supreme Court was shifted to New Delhi and the structure was changed. It was over the time that the Supreme Court evolved and the steps are mentioned below ${ }^{21}$.

The regulating act of the 1773, the King promulgated the regulating act, 1773, which posited the setting up of the Supreme Court of Judicature at Calcutta. The Letters patent appeal was issued in 1774 and this new court was made a court of record with the power to hear all the matters and pas sorders and judgements for the same. The Supreme Courts at Madras and Bombay were set up in 1800 and 1823 respectively ${ }^{22}$. With the coming up of the High courts Act 1861, the Supreme Courts were abolished and the High courts were established at these same places. They had the status of being the highest courts. However, the Federal court of India under the Government of India Act, 1935, the High courts continued their existence. The only difference was that they were made subordinate tot he main court, namely the federal court of India. this court adjudicated and resolved the conflicts between the High Courts of different provinces and settled points of law and legal language when in doubt. It was also empowered to resolve disputes between the provinces itself. It was Post Independence from the British that the Constitution of India, had a similar hierarchy with the Supreme Court being on the top replacing the Federal Court of India and the various High courts at the State level. It is therefore concluded from this chapter that the contributions of the British people in the setting up the Judicial system is invincible and amazing. the true impact of the British efforts can be stated in a line that they revamped the judicial system in India and made it more fair and accessible to the citizens of the country.

\section{CH-3. SUPREME COURT AS COURT OF RECORD}

The Supreme Court of India is considered to be the court of record and shall have the powers of such a court including the power to punish for the contempt of itself. The first draft of the Constitution of India was prepared by the Constitutional adviser under article 108, following section 203 of the Government of India Act, 1935, provided in clause 91 that the Supreme Court shall be the court of record. When Dr. B.R. Ambedkar, the chairman off the drafting committee was asked to define the status of the Supreme Court, he esclaimed and said that..... " a court of record is a court of records of which are admitted to be of evidentiary value and they are not to be questioned when they are produced before any court... Then the second part of Article 108 says that the court shall have the power to punish for the contempt of itself. As a matter of fact, once you make a court a court of record by statue, the power to punish for the contempt of itself necessarily follows from that position.." ${ }^{23}$ It means that according to Dr. B.R. Ambedkar, the nature of the provision of article 108 says that once the court is defined as the court of record and is vested with such power, it is the necessary thing that follows that it can punish for the contempt of itself which means that if someone does not follow the order of the Supreme Court, it is in the essence of the power, that it can punish that person.

Furthermore, Article 129 provides that the Supreme Court shall be a court of record and shall have all the powers of such court including the power to punish for the contempt of itslef. Article 215 contains similar provision in respect of the High Court. Both the Supreme Court as well as the High courts are courts of record having the powers to punish for the contempt including the power to punish for contempt of itself. They all are the similar provisions under different numbers. However, the court of record has not been defined in the Constitution, It is the common law.

\footnotetext{
21 Supreme Court Summary of the Evolution of the Judiciary, http://supremecourtofindia.nic.in/supct/ $\mathrm{scm} / \mathrm{m} 2$.pdf (visited on 4 February, 2017).

${ }^{22}$ Id. at 23.

${ }^{23}$ Constituent Assembly Debates, Vol. 8, p. 382.
} 


\section{A Court of Record is Defined as the Following :-}

(i) A court whereof the acts and the judicial proceedings are enrolled for a perpetual memorial and testimony, and which has the power to fine and imprison for contempt of its authority. ${ }^{24}$

(ii) Courts are either of record where their acts and judicial proceedings are enrolled for a perpetual memorial and testimony and they have a power to fine and imprison; or not of record being courts of inferior dignity, and in a less proper sense the Kings courts and these are not entrusted by law with any power to fine or imprison the subject of the realm, unless by the express provision of some Act of parliament. these proceedings are not enrolled or recorded ${ }^{25}$.

(iii) A Court of record is a court where the acts and judicial proceedings are enrolled permanently for perpetual memorial and testimony, which rolls are called the record of the court, and are of such high and super eminent authority that their truth is not to be questioned ${ }^{26}$.

(iv) The court of record in another manner of division is into court of record and courts not of record. Certain courts are expressly declared by statute to be courts of record. In the case of courts not expressly declared to be courts of record, the answer to the question whether a court is a court of record seems to depend in general upon whether it has the power to fine or imprison, by statue or by otherwise, for contempt of itself or other substantive offences; if it has such power, it seems that it is a court of record. Proceedings of a court of record preserved in its archives are called records and are conclusive evidence of that which is recorded therein ${ }^{27}$.

This is how the court of records has been defined and now coming to the Indian context as to how the Supreme Court of India is the court of record. The Supreme Court has emphasised upon the need for the concept of contempt of court in following words ${ }^{28}$ :-

"Availability of an independent judiciary and an atmosphere wherein the judge may act independently and fearlessly is the source of existence of civilisation in society. The writ issued by the court must be obeyed. It is the binding efficacy attaching with the commands of the court and the respect for the orders of the court which deter the aggrieved persons from taking the law in their own hands because they are assured of an efficacious civilised method of settlement of disputes being available to them wherein they shall be heard and their legitimate grievances redeemed. Any act or omission which undermines the dignity of the court is therefore viewed with the concern by the society and the court treats it as an obligation to zealously guard against any onslaught in its dignity".

The Supreme court exercises this power to punish an act which tends to interfere with the course of administration of justice. The following inter alia have been held to constitute contempt of court ${ }^{29}$ :

(a) insinuations derogatory to the dignity of the Court which are calculated to undermine the confidence of the people in the integrity of the Judges;

(b) an attempt by one party to prejudice the court against the another party to the action ;

(c) to stir up public feelings on the question pending before the court for the decision to be taken and to try to influence the Judge in favour of himself;

(d) an attempt to affect the minds of the judges and to deflect them from performing their duty by flattery or veiled threat;

(e) an act or publication which scandalises the Court attributing dishonesty to a Judge in the discharge of his functions;

(f) wilful disobedience or non compliance of the Court's order ${ }^{30}$.

In Hiralal Dixit ${ }^{31}$, the Supreme Court has observed that it is not necessary that there should be an actual interference with the course of administration of justice. It is enough if the offending act or

\footnotetext{
${ }^{24}$ Jowitt Dictionary of English Law.

${ }^{25}$ Wharton Law Lexicon

26 Words and Phrases (Permanent Edn.), Vol. 10, p. 429

${ }^{27}$ Halsbury Laws of England, Vol. 10, p. 319.

${ }^{28}$ Om Prakash Jaiswal v. D.K. Mittal, AIR 2000 SC 1136

${ }^{29}$ Hira Lal Dixit v. State of Uttar Pradesh, AIR 1954 SC 743

${ }^{30}$ Rajiv Chaudhary v. Jagdish Narain Khanna, (1996) 1 SCC 508.

${ }^{31}$ Hira Lal Dixit v. State of Uttar Pradesh, AIR 1954 SC 743
} 
publication tends in any way to so interfere. If there are insinuations made which are derogatory to the dignity of the court and are calculated to undermine the confidence of the people in the integrity of the judges, the conduct would amount to contempt of the court as discussed above also.

Contempt of court is committed when a court is scandalised by casting "unwarranted, uncalled for and unjustified aspersions on the integrity, ability and impartiality or fairness of a judge, in the discharge of his judicial functions as it amounts to an interference with the due course of administration of justice". ${ }^{32}$ Charging the judiciary as "an instrument of oppression", and the judges as "guided and dominated by the class hatred"'instinctively favouring the rich against the poor" has been held to constitute contempt of court as these words weaken the authority of the law and the law courts, and have the effect of lowering the prestige of the judges and the courts in the eyes of the people" ${ }^{133}$.

A distinction is drawn between a mere libel or defamation of a judge personally and what amounts to the contempt of court. A mere defamatory attack on a judge is not actionable but it becomes punishable when it is calculated to interfere with the due course of justice, or the proper administration of law by the court. Alternatively the test is whether the wrong is done to the Judge personally or the it is done to the public ${ }^{34}$.

Contempt of court is characterised either as civil or criminal. Any wilful disobedience of a court order to do or abstain from doing any act is civil contempt. Civil contempt arises when the power of the court is invoked or exercised to enforce obedience to court orders ${ }^{35}$. On the other hand, criminal contempt is criminal in nature. It includes outrages on judges in open court, defiant disobedience to the judges in the court, libels on judges or courts or interfering with the course of justice or any act which tends to prejudice the course of justice.

In Daphatory, the pamphlet in question ascribed bias and dishonesty to a Judge of the Supreme Court while acting in judicial capacity. This was made the basis of contempt proceedings against the respondent. Examining the scope of the contempt of court, the Supreme Court stated that the test was whether impugned publication was a mere defamatory attack on the Judge or whether it would interfere with the due course of justice or proper administration of law by the Court. On this test, the court found that the pamphlet contained scurrilous remarks about a Supreme Court Judge which amounted to gross contempt of the Judge and of the Court itself. The Court laid down the following general propositions regarding the scope of the concept of contempt of court.

(i) There is no excuse whatsoever for imputing dishonesty to a Judge even if it were to be assumed that the judgement contained numerous errors.

(ii) No evidence other than affidavits is allowed to justify allegation amounting to contempt of court.

(iii) In trying contempt of court, the Court can deal with the matter summarily and adopt its own procedure. However, the procedure must be fair. The Code of Criminal Procedure does not apply in the matters of contempt.

(iv) When the charge against the condemner is simple and clear, there is no need to draw up a formal charge by the court.

(v) The President of the Supreme Court Bar Association can bring to the notice of the Court any contempt of court as the Bar is vitally concerned in the maintenance of the Justice.

The Supreme Court also clarified the point that under the law, in case of contempt in the face of the Supreme Court (Criminal Contempt), The Supreme Court may take action either on its own motion, or on a non motion by the Attorney General or Solicitor General, or any other person with the consent of the Attorney General or the Solicitor General. If therefore, a citizen wants to initiate proceedings for contempt he has first to seek the consent in writing of the Attorney General or the Solicitor General. The Court further ruled that "Discretion vested in law officers of this Court to be used for public purpose in a society governed by rule of law is justifiable" ${ }^{36}$.

\footnotetext{
32 Jaswant Singh v. Virender Singh, (1995) Supp (1) SCC 384.

${ }^{33}$ E.M.S. Namboodiripad v. T.N. Nambiar, AIR 1970 SC 2015

${ }^{34}$ Rustom Cawasjee Cooper v. Union of India, AIR 19701318

${ }^{35}$ Delhi Development Authority v. Skipper Construction, (1995) 3 SCC 507.

${ }^{36}$ Pallav Seth v. Custodian, AIR 2001 SC 2763
} 


\section{CH-4. CONCLUSION}

It is from the beginning, during the British rule, India went through a great period of experimentation and emperical learning. No one knew what the results would be because of the difference in the behavioural patterns but one could always learn from the experience and that is what was happening with India. Many courts were created and then abolished and then replaced with new mechanisms to resolve disputes. The British rule in India had some positive effects on our legal system and the manner in which we administer justice is evident of the same. Rule of Law and importance of Independent Judiciary were introduced through the British. The concept of Separation of Powers was introduced and enunciated through their laws and policies. The federal system and the administration of Justice at the district level was also their creation and hence our legal system is something which has been derived from them. They increased the access to justice, permeating its reach to the smallest parts of the country and through the Law commissions India finally had a definite set of laws that could be applied uniformly ${ }^{37}$. The effect of these policies was felt post independence through Constitutional Law that we are today studying. Through their experimentation the Constituent Assembly was able to see what new practices and what old ancient practices could be coupled to form our new legal system after independence. Therefore, it is fair on our part to say that our legal system owes a lot to them since we have derived so much from them.

The Supreme Court is the highest court of the land and its decision is binding on all the lower courts. It is vested with some powers which are exercised by only few courts in the world. It constitutes the highest court of appeal in civil and criminal matters. Appeals against the order of any tribunal can also be entertained by the court by special leave. An overview of the constitutional and statutory provision justifies in establishing the pious character of our temple of justice.

\section{REFERENCES}

\section{Articles}

1. The Supreme Court as a Court of Record - By Manish Kumar Singh

2. The Evolution of the Judiciary

3. Understanding the Creation of the Indian Judicial System by Shambhavi Ravishankar

4. Essay on the Impact of British Rule on Indian Administration - Dayanesh Kumar

\section{Websites}

1. www.googlescholar.com

2. www.supremecourtofindia.nic.in

3. www.lawctopus.com

4. www.academike.com

5. www.legalservicesindia.com

Books

1. Law and Legal Institutions in Ancient India

2. Law and Legal Institutions in Medieval India

3. Law and Legal Institutions in Modern India

4. Indian Legal and Constitutional History, 6th Edition - M.P. Jain

5. Understanding the Creation of the Indian Judicial System by Char S.V. Desika

6. Administration of Justice in Ancient India - S.D. Sharma

\footnotetext{
37 Dyanesh Kumar, Essay on the Impact of British Rule on Indian Administration , (Sep, 27, 2011), http://www.preservearticles.com/2011092714107/essay-on-the-impact-of-british-rule-on-indianadministration.html.
} 